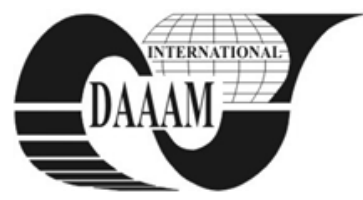

Annals of DAAAM for 2011 \& Proceedings of the 22nd International DAAAM Symposium, Volume 22, No. 1, ISSN 1726-9679 ISBN 978-3-901509-83-4, Editor B. Katalinic, Published by DAAAM International, Vienna, Austria, EU, 2011 Make Harmony between Technology and Nature, and Your Mind will Fly Free as a Bird Annals \& Proceedings of DAAAM International 2011

\title{
STRATEGIC MANAGEMENT OF ENGINEERING COMPANIES FOLLOWING SUSTAINABILITY DEVELOPMENT ASPECTS
}

\author{
KAISEROVA, V[eronika] \& SAKAL, P[eter]
}

\begin{abstract}
This contribution brings current standpoint to business strategies creation and show the needs to aim towards more global aspects - social and environmental one. Almost up to date have been used methods and key indicators which did not reflect true demands of business environment as a whole. Business strategies should be defined and created in another way and all the companies have to learn ensure the sustainability and usefulness of enterprise for as long as possible - and this is feasible just through the incorporating social and environmental aspects into own business strategies. Key words: corporate social responsibility, sustainable development, environmental and social values
\end{abstract}

\section{INTRODUCTION}

Creation and implementation of business strategy is one of the most important initiatives of each company and has Fig. significant role in case of the future success or failure on the market. Currently, when by passing the time are all demands for production processes, quality of products and services even in the engineering industry, is time to talk also about areas that are not much profitable and financially measurable in shortterm standpoint - those are the investments into the environmental and social fields (Barroso, 2010).

Impact of them could be shown in the long-term measure by considering the company as a strong social and environmental partner at the market place. And just the enterprises in business field of engineering should be most initiative, since range and manner of their impact mainly to the environment is apparent due to their business activities.

In spite of this fact there are still many companies that create their own strategy mainly with taking into account financial targets and commitments of enterprise, which usualy are the one standard point, indicator and evaluating point in process of creating the business strategy.

\section{CREATION OF BUSINESS STRATEGY}

All concepts, methods and tools how to create a efficient business strategy had the same principle - created strategy of business unit is aimed to raising financial profitability and higher net incomes (Kaplan \& Norton, 2002). By evolution of strategic management was created standardized model which is usually used as a template for strategy design (see Fig. 1). This type of business strategy creation do not reflect all the aspects that should be supported within company's strategic plan.

General strategic plan is in this case created of the functional strategies which one is corresponding and connected to the others. Through the summarization of the partial strategies we can gain overall business strategy - of course, just in case that all the standard processes and methods would be met.

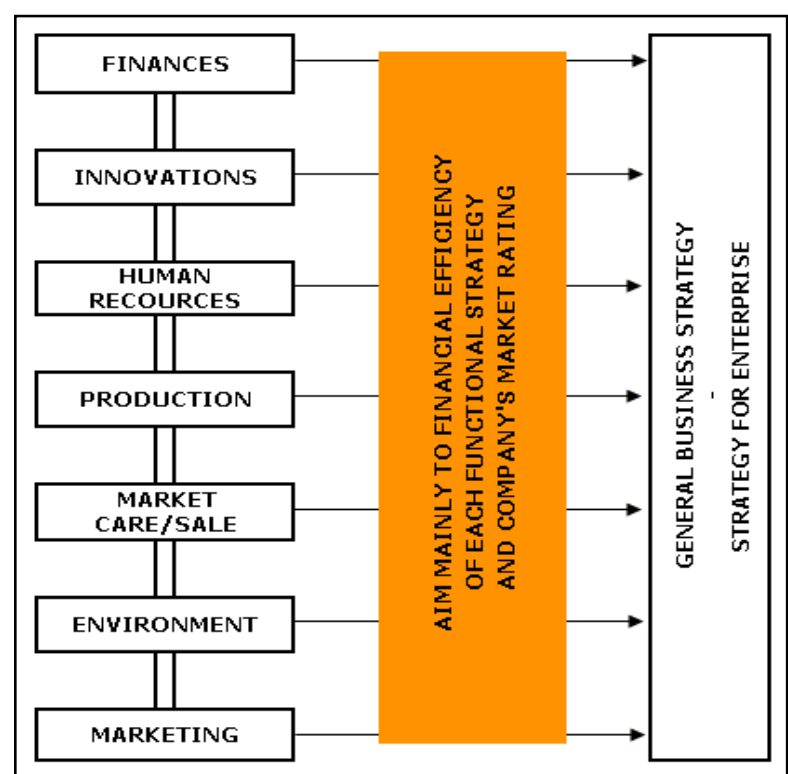

Fig.1. Business strategy following the basic principles (adjusted by Sakal, 2007)

Following the mentioned above had been designed new approaches how to build a strong company's strategy and how to ensure long-term sustainability at the market. Following new principles companies started with creation of environmental strategies. In this phase has the environmental strategy just the same status as the other functional strategies (Slavik, 1997).

\section{INCORPORATING OF SUSTAINABLE DEVELOPMENT AND CORPORATE SOCIAL RESPONSIBILITY INTO THE BUSINESS STRATEGY}

Initiatives of sustainable development and its follower corporate social responsibility - were created to support all efforts how to fulfill demands and tasks in environmental and social area according to the financial objectives of company. As we can see, both of them are aimed to the social field and also to environmental one (see Fig. 2 and Fig. 3).

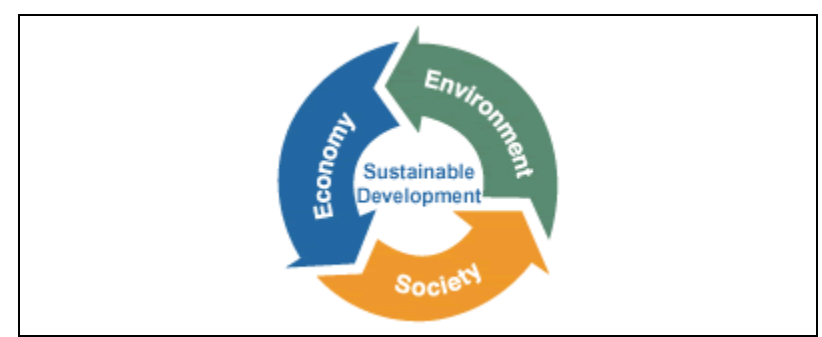

Fig. 2. Sustainable development 
One of the significant difference between those 2 models are its business orientation - since the sustainable development of company can we consider as more internal oriented, where are the main points how to ensure internal stability of enterprise, the initiative of corporate social responsibility is more widely and global oriented and there are the main relationships towards outside the company shown.

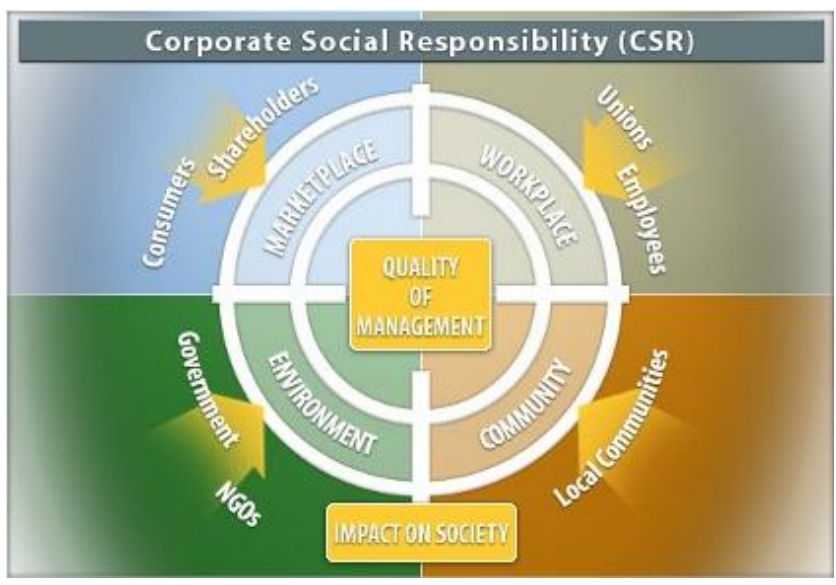

Fig. 3. Corporate Social Responsibility model

During the essential research within the engineering companies had been proved assumptions - companies have got the knowledge about those two initiatives but its implementation into their business strategies will be long-term. Reasoning of this can be more - domestic companies are very reserved towards any innovations, companies afraid on their investments raising and management of those companies is missing "open mind". Foreign engineering companies are much accessible to implement new tool which can be helpful for enterprise management.

\section{HOW CAN WE IMPROVE CREATION OF BUSINESS STRATEGY MODEL}

In comparison to the previous ways of business strategy creation is this manner much difficult for mutual coordination of targets and time depends but on the other hand this model is much wide and usable. The main principle consider creating of each functional strategy related to the other 2 aspects - social and environmental one.

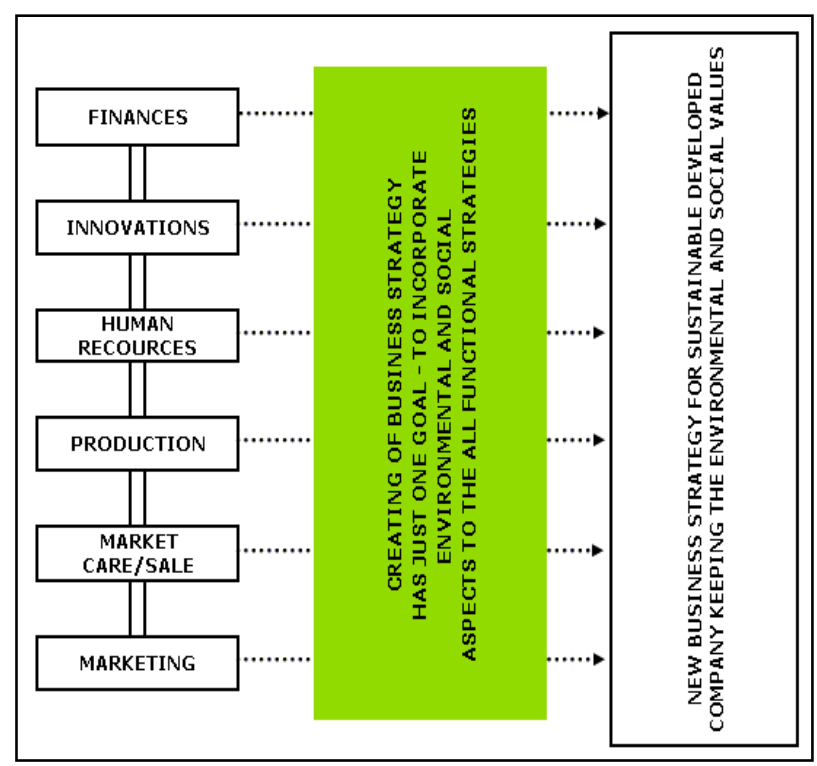

Fig. 4. Model of business strategy following environmental and social aspects (own proposal, based on research)
There are no functional fields where cannot be incorporated those two aspects. To get easier way for usage there can be created also new indicators which will be defined, evaluated and based on its results will be next steps in business strategy performed.

\section{CONCLUSION}

The aim of this paper is not to say and prove that the previous model of business strategy creation is really failed. We have just tried to show more ways how can the engineering companies - and not even they - use the provided tools.

Within the business strategy can be designed new model that will be really helpful in process of company's strategy creation. In this way can be fulfilled two objectives at the same time - to prepare a strategy for business unit and also meet the global targets to support sustainable development in environmental and social area. This goal should be met by incorporating social and environmental aspects into the creating of partial business strategies (financial, innovation, production partial strategy), see the Fig. 4.

\section{ACKNOWLEDGEMENTS}

This paper was supported by the Slovak Research and Development Agency under the contract No. LPP-0384-09: "Concept HCS model 3E vs. Concept Corporate Social Responsibility (CSR)."

The paper is also a part of submitted KEGA project No. 037STU-4/2012 "Implementation of the subject "Corporate Social responsibility Entrepreneurship" into the study programme Industrial management in the second degree at MTF STU Trnava”.

\section{REFERENCES}

Barroso, J.M. (2010)., European commision: communication from the commission. Europe 2020. - A strategy for smart, sustainable and inclusive growth. Brussels

Kaplan, S.R. Norton, D.P. (2002). Balanced Scorecard, Strategic measurement system for enterprise efficiency. Managment Press. Praha. ISBN 80-7261-063-5

Loew T., Ankele, K., Braun, S., Clausen, J. (2004). Significance of the CSR debate for sustainability and the requirements for companies. Future e.v. and Institute for Ecological economy research GMBH

Sakal, P. (2007). Strategic management in managerial practice. SP Synergia. Trnava, Sovakia. ISBN 978-80-89291-04-5

Slávik, S. (1997). Strategic management. Bratislava: Ekonóm, 1997. ISBN 80-225-0816-0

*** (2010) http://www.susdev.gov.hk/html/en/sd/index.htm, Accessed on: 2011-11-09

*** (2011) http://ec.europa.eu/europe2020/priorities/sustaina ble-growth/index_en.htm Accessed on: 2011-11-09

*** (2009) http://www.industryplayer.com/corporate_social _responsibility.php Accessed on: 2011-11-09 